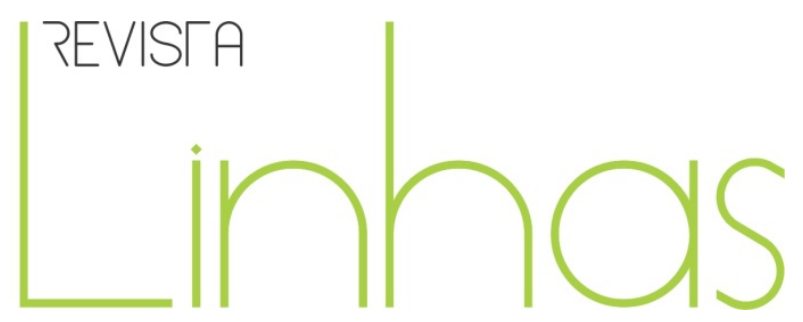

\title{
A pedagogy for the public: the place of objects, observation, mechanical production and cupboards ${ }^{1}$
}

\begin{abstract}
:
This paper has several significant themes compressed within it: the relation between the organization of mass schooling and its sustenance by simple technologies, the ways in which class and school routines bound objects and actions together, the particular relation between innovators and artifacts, and the economy and method of production of school artifacts. They are ways to approach the constitution of the process of schooling with particular attention to the material context that supported the ways that objects are given meaning within it. In this approach, we emphasize the pedagogic work around object lessons, revealing several meanings, each one connected to wider, but many times distinct analyses on schooling. The mechanic aspects of those tasks could fit in perfectly with the ideas of the Rational Factory and other organizations, since they were created in the XIX ${ }^{\text {th }}$ century. The pedagogy of learning implicit in the classes, which, in its own words, was sophisticated, could not be separated from the formalism and the mechanization of that period. Indeed Pestalozzi's ideas about objects and their use in schooling suggest they became widespread because they were capable of melding in with larger dominant themes about productive organizations and their realization through multiple and accumulating mechanized tasks. The objects, and the necessity to observe and to draw them, fit in with the thesis of technical literacy, a necessary skill in developing workers for the new industrial organizations.
\end{abstract}

Key-words: School material culture. School objects. Object lessons. School museums. Technical alphabetization.

\section{Para citar este artigo:}

LAWN, Martin. A Pedagogy for the Public: the place of objects, observation, mechanical production and cupboards. Revista Linhas, Florianópolis, v. 14, n. 26 , jan./jun. 2013. p. $244-264$.

DOI: $10.5965 / 1984723814262013244$

http://dx.doi.org/10.5965/1984723814262013244

\footnotetext{
'Source: "Materialities of Schooling: design, technology, objects, routines", organized by Martin Lawn and Ian Grosvenor (Symposium Books, 2005: pp. 145-162). This publication is part of the series "Comparative Histories of Education", which is organized by Martin Lawn and António Nóvoa. A Portuguese version of the text will be available soon.
} 


\title{
Uma pedagogia para o público: o lugar de objetos, observação, produção mecânica e armários-
}

\section{museus}

\begin{abstract}
Resumo:
Este artigo tem vários temas importantes condensados: a relação entre a organização da escolarização em massa e sua sustentação por meio de tecnologias simples, os modos pelos quais as rotinas das aulas e da escola ligavam objetos a ações, a relação especial entre inovadores e artefatos, e a economia e o método de produção destes artefatos escolares. São formas de abordar a constituição do processo de escolarização com ênfase no contexto material que a sustentou e as formas pelas quais os objetos ganham significado dentro dela. Nesta abordagem destaca-se o trabalho pedagógico centrado nas lições de coisas, revelando inúmeros significados, cada um ligado a análises mais amplas, mas muitas vezes distintas, sobre a escolarização. Os aspectos mecânicos das tarefas poderiam se encaixar perfeitamente nas ideias da Fábrica Racional e outras organizações, já que foram criadas no século XIX. A pedagogia da aprendizagem implícita nas aulas, que, em seus próprios termos, era sofisticada, não podia ser separada do formalismo e da mecanização do período. Na verdade, as ideias de Pestalozzi sobre os objetos e seus usos na educação sugerem que eles se generalizaram porque foram capazes de fundir-se com grandes temas dominantes sobre organizações produtivas e pela atividade através das múltiplas e acumulativas tarefas mecanizadas. Os objetos e a necessidade de observá-los e desenhá-los enquadram-se na tese da alfabetização técnica, uma habilidade necessária no desenvolvimento dos trabalhadores para as novas organizações industriais.
\end{abstract}

Palavras-chave: Cultura material escolar. Objetos da escola. Lições de coisas. Museus escolares.

Alfabetização técnica. 


\section{Introduction}

The past emphasis in studies of schooling has tended to avoid the material context of the school and the ways that objects are given meaning within it, how they are used, and how they are linked into heterogeneus active networks, in which people, objects and routines are closely connected. The rise of schooling has been inclined to prioritize state building, professionalism, innovation or the sciences of education as its main themes. Interest in materiality of schooling has tended to stay with museum specialists not historians of education. Yet pencils, cheap paper, colour printing and intelligence test are the tools of schooling, and without these tools and the systems of use they are contained within, the grand narratives of education would be unable to function.

This paper has several significant themes compressed within it: the relation between the organization of mass schooling and its sustenance by simple technologies, the ways in which class and school routines bound objects and actions together, the particular relation between innovators and artefacts, and the economy and method of production of school artefacts. For historians, the question of how objects and routines arrive in school, how they exist there and what happens to them could open up the less visible aspects of school history. The problems we have are to do with their existence in schools and their operational use, including their shift from innovation to sedimented or lost existence. Schools appear to begin their existence designed to incorporate new technologies of education (tools and systems) and yet very soon after, parts of the school resemble museums of technologies. They soon become sites of layers of sedimented materials as they slowly accumulate texts and tools. They are also repositories for outside objects, filtered through the net of poor financial resources in the school. Nor do tools just disappear; as they are always contained within rules of practice and specific meanings, they continue as outdated but useful pieces of equipment long beyond their time of innovation, and may even develop new meanings for new school purposes.

The focus of this essay is upon the arrival in early elementary school classrooms, in the late Victorian period, of a range of objects or their representations. This was unusual in itself as these classrooms mainly depended upon rote learning exercises and oral recitations, as much as slates and blackboards, and were often bare except for a few art 
reproductions on the walls. Objects for purposes other than recording and punishing were not common in the classroom at that point. The necessity to provide object lessons, and nature study, meant that provision had to be made to teach from objects, with a special and unvaried mechanical technique, and to find suitable objects for class use. Schools then had to develop storage capacity for the objects they used.

Objects were not randomly collected but intimately joined to a set of instruction and routines, used within a fixed time period, and open to rigorous inspection. They involved a sequence of often perplexing questions and answers which had to be repeated to assure success in annual inspection; success which had financial consequences for the school. Providing these almost official objects had financial consequences as well as the school did not have its own or special monies to acquire them. State schools became part of a suppliant group, developing a direct relation with commercial suppliers for the first time, and trying to acquire free samples of their wares. One significant outcome of the rise of object lessons was a new relation to business, which developed its own logic in later years as business entreprises recognized schooling as a place of advertising, and of developing new customers. These «Objects » then are not separated and disconnected artefacts ; they are surrounded by social value and are dynamic in their effects.

\section{Objects}

Before the arrival of the designed school and the organized classroom, schooling in dame and village rooms had their own necessary objects including the stool, the bench, the quill, the switch and the book. With these objects, bought or made, order and learning were organized. In England, the advent of state schools and a prescribed curriculum permitted a range of tools and objects to arrive in their wake. Class subjects, in addition to the basic subjects of reading, writing and arithmetic, were introduced in 1875 ; grammar, geography, history and needlework were to be taught throughout the school, and were examined by a whole-class inspection. Natural sciences were added to the curriculum in 1871 , as an optional subject, with a note on the need to 'study ... natural objects and from careful direction of their powerof observation' (Birchenough, 1938, p. 
309). By 1882, it had become a class subject for all Standards and in 1895, the object lesson had become compulsory for the lower Standards. Revised Instructions to HMI (Her Majesty's Inspectorate) stated that after 31 August 1895, object lessons and suitable occupations shall form part of the ordinary instruction in Standards1, 11 and 111 (Code 1894).

In order to satisfy the second of three requirements of Art. 98b (new Code) the mistress early in the school year, should draw up, and enter in the Log book, a course of about 30 collective lessons - eg on animals; on such objects as coal, glass and salt; on common employments, as paper making, cotton mill, house building; one of the trades of the district being chosen in preference ; on form and colour, food, plants, and clothing; on simple facts in nature, as rain, frost, the seasons; and on familiar scenes in common life, as the post office, a shop, a railway, washing, or harvest. Each of these should, in the course of the school year, be given by the teacher in charge of the class; then, at the point of lesson where questioning begins, (the inspector) may himself intervene and ascertain how far the lesson has had an intelligent effect (Education 1894).

In later years, especially after 1902 when the system of school government altered, nature study grew in significance as well.

In some localities the education authority has devised a scheme for supplyning schools, at regular intervals, with botanical specimens for nature study, drawing and botany. In one large area these specimens gathered from the parks and other open spaces, are sent fortnightly to the elementary schools, and weekly to secondary schools and colleges... In addition to these means, a yearly allowance of some shillings is made to each department - proportionally to size - to cover purchases in connection with object lessons and natures study (Bray, 1924, p. 382).

So, the relation between objects, observation and a specified curriculum focused on the class lesson became established as a formal arrangement, introduction a wide range of objects into classrooms. With quite firm instructions as to the content, the teacher had to organize object lessons, according to the age of the child, and in doing so, had to manage order, learning and routine in new, complex ways.

\section{Why use objects?}

Why was there this emphasis on objects? Where did it come from? Although subjects were being added to the Elementary Code, according to ideas of economic competition, imperial knowledge or a child's needs (to know about scientific ideas), and the use of objects practical in the exposition of the subject, the observation of objects 
had a significant history, with which it was closely connected. Objects were to be used within a Pestalozzian framework. When they were viewed, it was in a certain set of relations, a pedagogic and knowledge code. They had to be viewed, touched and drawn in certain ways. Books on elementary teaching, produced between 1880 and 1910, for example, made little reference to this Pestalozzian frame directly, that is, that objects were to be used in the way he suggested, except by the use of the term 'observation'. Perhaps this was because the frame in which 'objects' were placed had weakened over time. Pestalozzi used the term Anschauung to describe the immediate experience or intuitive apprehension of things, within a gradual sequence of instruction following the strictest psychological order. Its purpose lies beyond more 'observation' as it included sensory impression (in modalities other than visual). Its fundamental aspects were form, number and language ; key questions to be asked of the object were their number, their kind, their appearance or form and their names.

$[\mathrm{T}]$ he whole sum of the external properties of any object is comprised in its outline and its number, and is brought home to my consciousness through language (Pestalozzi, cited in Rusk, 1965, p. 189).

The focus was on the elemental object, the static object, seen as a single unit, separated from those with which it is connected, and emphasizing its size, proportions and associated names. It should address the 'primary faculties of counting, measuring and speaking'. Using form, number and name, knowledge of the object becomes 'precise' :

by gradually learning its other qualities my knowledge of it becomes clear; through my consciousness of all its characteristics, my knowledge of it becomes distinct (Pestalozzi, cited in Rusk, 1965, p. 190).

Pestalozzi felt that common popular instruction could not advance unless formulas of instruction are found which make the teacher 'merely the mechanical tool of a method, the result of which springs from the nature of the formulas and not from the skill of the man who uses it' (Pestalozzi, cited in Rusk, 1965, p. 184). Under Pestalozzi's method (the formulas), the teacher taught the whole class as a group, framing questions in accordance with the understanding reflected in their answers to previous questions. This method challenged the resourcefulness of the teacher, since it demanded 
knowledge of the subject within its subject context as well as competence in questioning and class management. Versions of this method, learning through object teaching, had operated in the Germain states earlier in the century, and 'had been widely spread by early educacional journals, professional text books, and official reports of Pestalozzian schools in Europe' (Saettler, 1968, p.40).

In England, the Mayos published books on object teaching and organized an infant school (Home and Colonial) for the upper classes. A manual on object teaching, produced by them, first published in 1830, went through 26 editions (in 1855, it had only reached its 14th impression).

The lessons were arranged in five series. The first series contained simple list of qualities; for example, in the case of leather it was stated that it was flexible, odorous, waterproof, tough, smooth, durable, opaque. The second series gave parts of complicated objects as well as qualities. The third series include non-sensory qualities such as 'valuable' and such classifications as 'artificial' and 'natural'. The fourth series continued the classifications and proceeded to discover analogies between physical and moral and spiritual qualities. The fifth series provided exercices for composition, containing lessons on various chemical substances, on solubility, on the five senses (Parker, 1912, p. 362).

Pestalozzi and his interpreters had also influenced the growth of drawing in America between 1825 and 1840. It had gained an important foothold in the USA, especially in Oswego by 1860, developing into a pedagogic system built around object teaching, which Saettler argues 'soon assumed a formalism of its own and sometimes became as verbal and mechanistic' (1968, p. 40)as the older class methods.

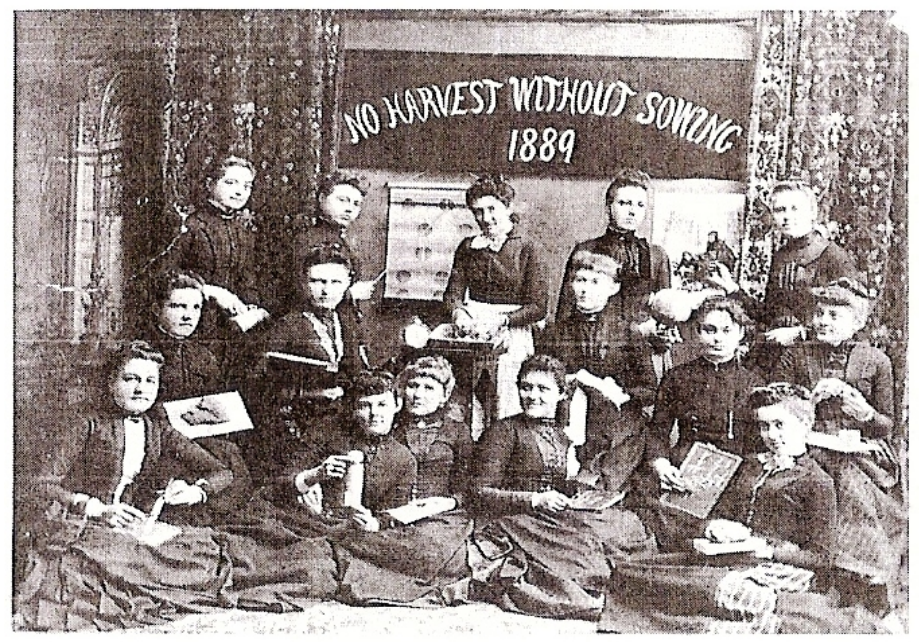


The object method became highly fashionable in the 1860 s and was seen as progressive. Everything could be taught this way (and not by reading and writing). Later, a looser 'play' version of the method, developed in Massachusetts, pushed the definition of the object further, and local parents 'criticized [it] for changing their schools into « natural history museums » and «mud-pie factories »(Saettler, 1968, p. 41). It revived again later when nature study was introduced in the USA in the 1880 s and early 1900 s in the first-hand study of animals, insects, minerals and plants.

According to Stevens (1995), as labour became the subject of the new discipline in the factory, the object of man-machine relations, the relation between material aspects of technology and their use became important. Stevens argues that technical literacy, a new skill, was needed in which, to the skills of reading, writing and arithmetic, was added 'spacial graphical representation'. The importance of observation, of drawing, and of three-dimensional objects were all important bridges to the problems of mechanical innovation, a practical world which the overly verbal world of schooling avoides (Stevens, 1995, pp. 3-41).

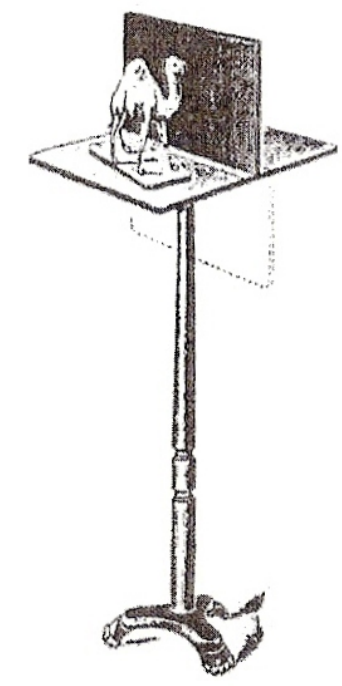

FIGURE 2. Object stand

Models were the key artefacts in translation the practical and the abstract world together, so necessary for improvements in production and a skilled workforce. 
At the elementary level of instruction it was the skill of drawing and the manual dexterity needed for building models that received most attention. Drawing as a skill was seen simply as a different way of writing. Moreover it fit nicely with the emergence of Pestalozzian hands-on methods of teaching (Stevens, 1995, p. 49).

The rise of apparatus, and the new marketing of commodities for the classroom in America, from 1840 s, was due to this need form mechanical drawing and scientific observation.

\section{Using objects : mechanical relations}

In the English elementary school, the object lesson arrived with a series of pedagogic injunctions about how it was to be operated, a close reference to the Pestalozzian notion that the teacher should be a mechanical tool of the method. A paradox appears when the formulaic method is counterpoised by the expected pupil outcome :

- To teach the children to observe, compare and contrast.

- To impart information concerning common objects surrounding them.

- To reinforce the first two by making the results of them the basis for instruction in language, drawing, number, modeling and other handwork.

The purpose of this branch of instruction [natural science] is to beget an intelligent interest in the objects that surrounds us, so that we may really see something when we look at them; and thus to induce a certain mental attitude towards these objects so that the curiosity with which a young child looks out upon the world may not be nipped in the bud (Raymont, 1937, p. 142).

Trained attention and accurate observation were mentioned in Government Circular 369. Detailed advice filled the pages of the educational press, like Teachers' Aid and the key examining guides (Cowham, 1894 ; Gunn, 1895 ; Flux, 1896) of the time :

The object should be exhibited, if it be a substance [such as glass ou sugar], for the inspection of the class; and the qualities important to be noticed should be observed by the appropriate senses. The action of the several senses is not to be interchanged; this is a quality cognizable by touch alone, such as hardness, [it] is not to be vouched for by the sight, but verified by the sense of touch. The actual inspection of the aggregate of the qualities must be so distributed over the class, that as little shall be taken by them on trust as possible (Currie, 1871, p. 142).

Books produced at the time offered advice about how the lesson should operate. Obviously it raised difficulties, which were different to the blackboard or slate based repetitions of the normal class. Preparing for the subject, writing lesson notes 
beforehand, making them concise, thinking about the right introduction using the blackboard, arranging the object, ordering the 'discovery' and technical vocabulary, were all advised about.

This was a heavily choreographed and condensed lesson, with each part dependent on the next. They could so easily go wrong :

Schemes of object lessons were commonly devised for the purpose of imparting 'useful knowledge' and without references to the child's experience and interests, so that a child in a city school might perhaps be told much about the rotation of crops, whilst lessons on coal mines and on the manufacture of silk and glass might be given in a school situated in a purely agricultural district. The inevitable results were that, whatever the pains the teacher might take to illustrate his lessons suitably, the instruction became, on the whole, merely verbal, and the pupil remained passive. Moreover the sound principle that elaborate classifications and comparisions are to be eschewed, and that therefore the main interest in each lesson should centre in the object itself, rather than its relations to other objects, was travestied by lists of lessons on subjects of the most heterogeneous nature, in which thought, as distinguished from observation, was conspicuous by its absence (Raymont, 1937, p. 143).

An experienced teacher describes the difficulties of its operation :

One has a potato, or an ear of wheat, or teacup, and one elicits its properties thus - 'now if I hold it up to the light can I see throught it ?' a shower of hands - one points to one of them and the answer comes 'No' 'How do you describe a thing through which you cannot see' - hands again and an answer 'you say it is opaque'. A quick girl learns to do this thing in no time but the dull ones require a long and slow priming before they are ready to fire their answer off at any target which an Inspector may hold up. One requires a great deal of experience before one can distribute objects to a large number of girls, get the required answers from the dullest, and yet keep the quick occupied, and then collect one's objects neatly again at the signal of the ringing bell, or while, perhaps, another class are standing at the door of the classroom waiting to come in (Debary, 1913, p. 20).

Even when they were successfully managed, they still had to show evidence of an improvement in the child's observation and reasoning and improvement in general knowledge.

Pupil teachers, trained in the school, were always searching for knowledge and information about object lessons for their examination. An examination might look like this :

Write full notes of a lesson on one of the following subjects - for infants 
A bird nest

An oak tree

A railway ticket

A stream hammer

The Suez Canal

The Armada

The Revolution of 1688

The Alps

The Conquest of Wales

Make a list of object lessons suited either for an infant class or for older children. Show in which of the subjects you would think one lesson sufficient, and to which you would assign two or more lessons.

What sort of sketch should appear on the blackboard at the end of a collective lesson on one of these objects - Iron ; Corn ; the Ocean - and what is the best use to make of such a sketch when it is written?

Make a list of twenty lessons on familiar animals, and explain the order in which you have arranged them.

Detail the apparatus required for lessons on a coalmine, and on the seasons, and draw the diagrams required for the latter. What sort of objects would you desire to collect in a school museum and how would you classify them and use them? (Teachers'Aid, passim, 1899/1900 - extracts from advice columns to pupil teachers on examination practice)

Inspectors were damning in the reports on object lessons, for example, in Birmingham:

Dixon Road Girls School Nov 22nd 1898 [follow-up instruction] Object Lessons [headteacher had spent a lot of time over them]

the want of blackboard illustrations and also expertise on the part of the teachers in performing very simple experiments. The Headmistress has been at great pains in procuring suitable objects and diagrams. Elementary Science - Inspection 1877-8.[1]

there are certain so-called 'object lessons' that come upon me like the repetitions of a hideous dream ... I know what the questions will be, I know what the children will answer, and I know what is coming next. And then I see the fatal apparatus got ready, the black board and the chalk, and the picture card, or the object - the 'camel' or the 'lump of coal' - and the victims are also ready on their gallery with an air of resignation [for they know it all too] and the pupil teacher with her best manner surveys her class and then - and I am told [or that the children are told] that the object before them is 'opaque' or 'tangible' or 'transparent' or what not ; or else that the animal is 'gregarious' or 'carnivorous' or a 'marsupial' ; and all that is 
carefully written on the blackboard and the words repeated by the children, and so on till the fatal twenty minutes have expired.[2]

\section{Searching for objects}

The growth of the object in lesson in the school, the growth of elementary schools in the late nineteenth century, and the receipt of the Inspectors' reporting for action, meant that the local School Boards were focused upon this subject in their annual reports on management. The Management Sub Committee of Birmingham School Board, in its 1887 Annual Report, reported that the:

Committee feel pleasure in acknowledging gifts of a case of different kinds of gums from Messrs Dale and Plant, and of 6 cards of specimen forks and spoons in rough slates of manufacture from Mr H A Wiggins, as well as several previous gifts, inc cards showing steel pens in various stages of manufacture from Messrs Perry and Co and a case showing the chemical constituents of the human body, from Messrs Southall Bros and Barclay. The teachers are endeavoring to form museums of Objects useful for lessons, and several schools have already obtained very good collections in this way. Manufacturers and others may assist this effort very materially, and it is believed they will if their attention is drawn to it (Annual Report, 1889, p. 45).

The Board gratefully acknowledges the gift of a number of articles for the School Museums, which were obtained from the Black Forest by the Rev WF Clarkson, with the assistance of several of his friends. Small but increasing Museums are to be found in nearly every school, and the objects are exceedingly valuable for illustrating lessons. Several manufacturers have also kindly assisted the teachers in making these Museums (p. 40 ditto 1890).

Gifts from Rev Clarkson acknowledged (Annual Report, 1890).

Miss Kenrick for the gift, for the Infant Museums, of a number of objects for lessons (Annual Report, 1890).

Objects lessons have been given without the "object" and the amount of information acquired is meagre (Inspection Minutes, 25 February 1901). 
Schools had to teach the object lessons, which were built around real objects (as well representations). Whenever the object lesson is explored, generally reference is made to an Object and a Blackboard. Anything else was not regarded as a proper object lesson. But, as Gunn says, "pictures and diagrams [may be used] such as are now found to however inadequate extent in every school” (Gunn, 1895, p. 148).

The difficult in not using them can be ascertained from the list of lessons suggested in the regulations. They included:

- Animals - "Stuffed specimens, models, pictures...";

- Minerals - specimens of peat and different kinds of coal, sand, different kinds of glass, salt, slate, chalk, marble, flint, pebbles;

- Clotting Wool (raw wool, cloth, pictures of sheep) - silk (eggs, silkworm, cocoon and moth, silk thread and silk material - instead of mulberry leaves, clean lettuce leaves for feeding the silkworms may be used)

- Food - Butter (milk, cream cardboard model of milk churn, butter and buttermilk for a special lesson, with picture of diary)

- Fruits and Vegetables - specimens of finest grown in locality - suggest market garden for school - "at times it would be advisable to replace one set of objects by a fresh group" (Cowham, 1894, p143).

I have argued before that English schools lived within a "Make Do and Mend" culture in which the school :

Survived without significant purchase power, it found solutions which didn't involve expenditure and it conserved and re-used any found material. It was a barter economy, a "bagged and borrowed" approach and most of all, it symbolized a culture, denoted in some regions by the expression "make do and mend". Teachers reflected a time in which people solved their work problem by making their own solutions - a craft approach - and a school economy that had no significant financial resources of its (Lawn \& Grosvenor, 2001, p. 125).

Teachers operated by "craft and barter". At the turn of the last century, magazines were produced for teachers which offered practical solutions to the pressing problems of resources, inspection and examination. Model exam questions, reports of school inspection, timetable solutions and "wrinkles" existed alongside practical question and answers; for example, "where to get cheap globes" (1, p. 190), a Manual of Military drill (1, p.170). Ideal Object Lessons were offered by teachers: so, for example, a lesson on a River would need a map of England, a diagram of a River, coloured pictures of a river basin, clay model of a river bed, sponge, slate and a water can (31, p. 87). A lesson on a 
Soap needed different kinds of soap, a glass of water, bowl of water, soda, lime and tallow, palm and coconut oil! (method includes - can out a dirty child!) (31, p. 87). [3]

\section{Collecting and Storing Objects: the museum}

So, finding and storing objects became an important issue for the school. Teachers' Aid ran a series of articles on the School Museum, and after the first one received hundreds of applications for further information. "We feel assured that there is a strong will on the part of many teachers to possess a really up-to-date museum cupboard filled with 'handy objects"”. [4]

Later, in this article, the author wrote that he hoped he had proved of service to "hall those who are striving to keep themselves in the foremost ranks in the great educational movements that we all find ourselves associated with in these go-ahead days".

How to find objects to be used in the class object lesson without a budget? The advice offered to the reader was simple. Write to suppliers, working in commerce or manufacturing, who might supply samples or models for free or a little cost. The same article consists of key directories and magazines of manufacturing, shippers, engineers, ironmongers, drapers, grocers, collieries and other trades. The author recommends them as useful sources of information, and in such a way that it appears that teachers had not been thinking of approaching them before. This was new. Among the exhibits which the author had gained from these sources are mentioned:

Coal tar products

Asbestos

Pottery Ammunition Wire ropes Locks and keys Cutlery

Nails and needles

Electric bells

Model of a ship

Electric light specimens Cotton

A further article, later in the year [5] describes in more detail the magpie nature of this teacher's life: he had obtained: 
Carpets - costly collection, comprising dyed yarns, a carpet in process, four finished rugs, measuring two yards by one, of the following - Brussels, Wilton and two Axminsters.

Ammunition - shell cases made of solid brass - a specimen of a twelve pounder, nine pounder and a six pounder, samples of electric cartridges, pom-poms and rifle cartridges, free of cost

Wire Rope and Cable - a black ebony [a yard by 2 feet] case, a glass face, lined with green baize, containing 16 examples of deep sea and electric cable plus 16 of wire rope of different thicknesses plus other coils of copper wire etc

Natural History - 4 large cards showing fresh water fish, salt water fish, reptiles and beetles and seashore etc - free of cost

The author does mention that some manufacturers are failing to respond! Yet he often says that 'we simply asked and received them free of cost' or the 'cabinets cost nothing but simply asking for'. In addition, his school museum contained 57 mineral ores (from all over the world, including silver from Bolivia), flags (flags of all nations wall chart, British colonies, silk banners, books of designs and samples), a case of spoons, a Sheffield steep razor case, photo engraving blocks, a leather case off needles, miners lamps, and nearly 40 samples of shale products (coke, paraffin wax, etc.).[6] Teachers' Aid produced charts of firms 'who were kindly disposed to help teachers'; they could provide buttons, cork, soap, pens, salt, cornflour, sponges, mustard, matches, candles, pencils, linen cocoa and paper, etc.[7]

GSBRETS OF ACTUAL OBJECTS FOR OHJECT LEESOHS.

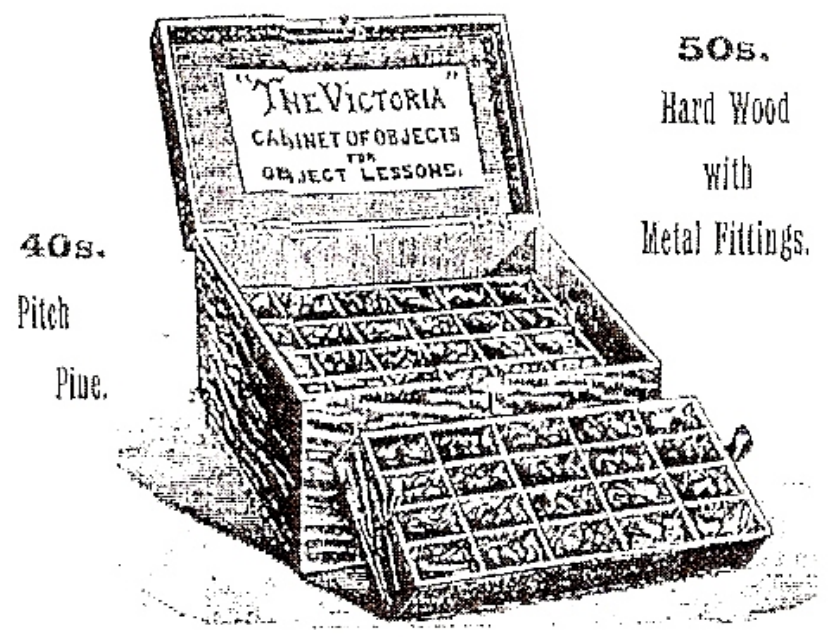

Figure 3. An early commercial object box. 
In 1900, Teachers' Aid described companies who were willing to lend magic lantern slides to schools, sometimes with accompanying lecturers. In particular, colony agents, travel agents and steamship companies were willing to provide slides about South Africa, Canada and Tasmania, for example; sets of 50 or 100 slides could be sent entirely free of cost to the school, paid for by the Empire governments. Many firms had produced slides about the Boer War, which could be hired. Other slide sets on British battles, the Queens, London, Nelson, the Bible or popular artists could be borrowed easily.

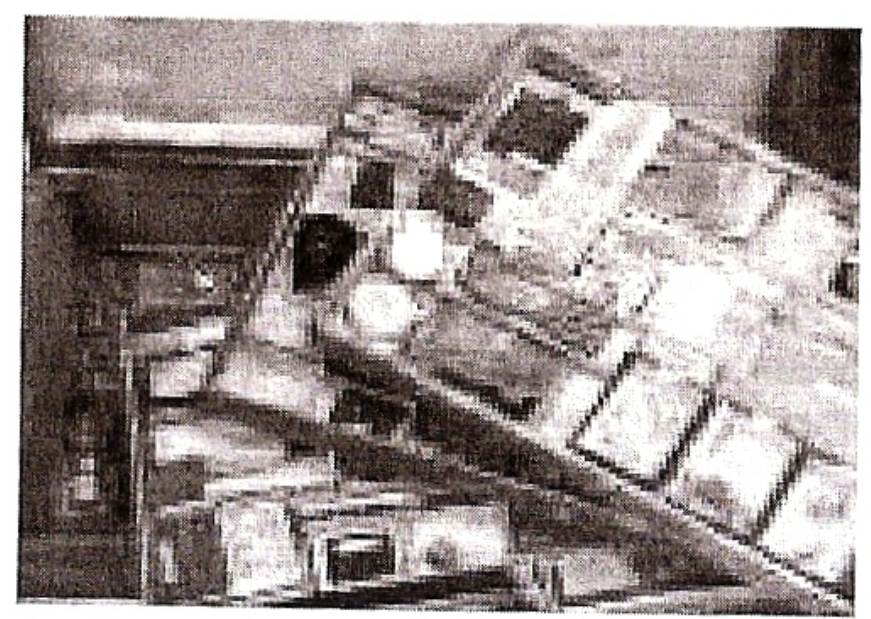

Figure 4. A series of object trays.

\section{Cupboards for Classification}

The creation of the object lesson, and its growth inside the elementary school curriculum, made it necessary to provide storage for the objects. This became a pressing problem in itself.

The Birmingham School Board Committee Minute Book 1890-98 (Inspection of Hope St Mixed School 8 June 1896) mentions this difficulty.

There is a cupboard containing apparatus for teaching science in one of the classrooms and the Head master wishes to use the contents for illustrating object lessons.

Within a couple of years, the issue had entered the minutes of the whole School Board.[8] The chairman of the Board had to take action about storing objects in the city schools. 
That this Committee considers it of educational importance that Museum Cupboards should be supplied to the Infant Departments of the Board Schools and will be glad if the Sites and Buildings Committee will comply with the requests of the Head teacher for the cupboards to be provided'. (Min. 4230)

It was moved by Mr Kenrick, seconded by Dr Langford, and resolved, that a loan be raised for the purpose of defraying the cost of museum cupboards to be supplied to all the Infants schools under the Board. (Min. 6503, p. 248)

Moved by the Chairman, seconded by Cllr Stevens, and resolved that application be made to the City Council for loans to defray the cost of providing Schools in New Bridge Street and Upper Garrison lane, the site in Muntz and Aston Brook Street with Museum Cupboards and that the Chairman or vice Chairman of the Boards, be hereby authorized to sign and seal all necessary documents connected with the obtaining of such loans. (Min. 6594, p. 361)

Models for drawing supplied to Boys depts. (Min. 3158)

Pictures illustrative of agricultural pursuits and copies of 'Armada in sight. (Min. 3292)

The pressure to keep up with good practice in schools, and schools were showing a lot of initiative in pushing forwards the range of objects they used, meant that the demand for cabinets and cupboards was coming from progressive School Boards and leading schools. Books for the school manager and class teacher, at the time, emphasized the need for developing the idea of the cupboard. It should not be a random collection, based upon rehearsed object lessons, but the schools' own cabinet of curiosity.

Each school should have a First Aid equipment, proper accommodation for ink trays, and a museum case, the last named to contain only such objects as are likely to be generally useful in illustrating lessons. The case should not, therefore, be used, as it frequently is, for a collection of curiosities that are rarely moved from their positions, and occupy space that could be better filled by really serviceable objects. It is well to encourage the scholars to assist in furnishing a cupboard of this kind, the omnium gatherum principle being strictly tabooed (Bray, 1924, pp. 59$60)$.

Just as the literacy part of instruction is furthered by the school library, so is the scientific part helped by the school museum. The distinction is not, of course, a sharp one since the library will contain scientific books, and the museum may contain aids to the study of history and literature. The great thing to be avoided in the formation of the museum in making it a mere dumping ground for such miscellaneous odds and ends as any one interested in the school may care to contribute. Many such articles are more suitably stored in cupboards, and some more appropriately consigned to the dust heap, than exhibited in museum cases. The museum should contain, above all else, illustrations of the fauna and 
flora, the geography and geology, the industries and the history, of the district in which the school is situated. If the museum is to serve any useful purpose, and to contribute to the intellectual life of the school, the specimens it contains should not be thrown together anyhow, as is too often the case, but should be duly classified and labeled (Raymont, 1937, p. 277).

Again, Stevens argued, from the earlier work of the American common school, that:

The first step for schools planning to expand their curricula to include science was to construct or provide a 'cabinet'. The cabinet tradition in mechanics institute and inventors associations, served to display models of the organization. Everything from stones to skeletons, levers, and electrical apparatus found a place. The articles were used as demonstration apparatus in the classroom and in exhibitions (Stevens, 1995, p. 74).

Objects lessons begat objects which begat cabinets. The series of events which lead from a curriculum instruction to a minor industry of object supply and the creation of school cabinets or museums took place within a few years in many state schoo.

\section{Conclusion}

The history of object lessons uncovers layers of meaning, each linked to wider but often distinct analyses about schooling. The mechanical aspects of the task could easily fit within the ideas of the Rational Factory and other organizations, as they were created in the nineteenth century. The pedagogy of learning which the lessons enclosed, which, on its own terms, was sophisticated, cannot be separated from the formalism and mechanization of the period. Indeed Pestalozzi's ideas about objects and their use in schooling suggest they became widespread because they were capable of melding in with larger dominant themes about productive organizations and their realization through multiple and accumulating mechanized tasks. The objects, and the necessity to observe and to draw them, fit in with the thesis of technical literacy, a necessary skill in developing workers for the new industrial organizations. The idiosyncratic nature of the inserted lessons seems rather less exposed when treated in this way.

The idea of a rational factory, that is, a factory that could run like a great machine, grew in strength during the nineteenth century. The factory would be the master 
machine organizing and controlling work (Biggs, 1996, pp. 2-6). Firstly, operations were 'mechanized' and secondly, they were standardized and related the entire process. The systematization of production and the tightly specified planning of work tasks operated unevenly across different fields of production but even schooling owes something to this movement, If all else in the elementary school is left aside for the moment, the object lesson serves as an exemplar of a tightly specified and inspected task, inserted into the curriculum to fulfil its mission to provide technical literacy. In some ways, it was quite progressive; it involved stages of learning theory, real objects, museum cupboards, science and drawing. What it lacked was a means of resourcing the provision of objects, and it relied upon the willingness of teachers to find or make these objects or to approach companies to provide them. It also lacked a view of the school that it was infinitely capable of adjustment, as a 'great machine' open to experiment as piece of production technology.

\section{References}

BIGGS, L. (1996) The Rational Factory - architecture, technology and work in America's age of mass production. Baltimore: Johns Hopkins University Press.

BIRCHENOUGH, C. (1938) History of Elementary Education in England and Wales. London: University Tutorial Press.

BRAY, S.E. (1924) School Organization. London: University Tutorial Press.

COWHAN, J. (1894) School Organization, Hygiene and Discipline, 3rd edn. London: Westminster School Book Depot.

CURRIE, J. (1871) The Principles and Practices of Common School Education. Edinburgh: Thomas Laurie Publishers.

DEBARY, A.B. (1913) Letters of a Schoolma'am. London: Vineyard Press.

FLUX, A. T. (1896) Pupil Teachers and Scholarship School Management. London: Nelson and Sons.

GUNN, J. (1895) Class Teaching and Management. London: Nelson and Sons.

LAWN, M. \& Grosvenor, I. (2001) 'When in Doubt Preserve": exploring the traces of teaching and material culture in English schools, History of Education, 30, pp. 117-127 
PARKER, S.C. (1912) A Textbook in the History of Modern Elementary Education. New York: Ginn and Co.

PESTALOZZI, J. H. (1894) How Gertrude Teaches her Children. London: Swan Sonnenschein.

RAYMONT, T. (1937). A History of the Education of Young Children. London: Longmans, Green \& Co.

RUSK, R. (1965) Doctrines of the Great Educators. London: Holt Rinehart \& Wilson.

SAETTLER, P. (1968) A History of Instructional Technology. New York: McGraw-Hill.

SMITH, F. (1931) A History of English Elementary Education 1760-1902. London: London Univ. Press.

STEVENS, E. (1995) The Grammar of the Machine - technical literacy and early industrial expansion in the US. New Haven: Yale University Press.

\section{Notes}

[1] Report of Education Department 1877-8, in Smith (1931, p. 151).

[2] Birmingham School Board Records, pp. 438-439, in Smith (1931, p. 310).

[3] All the references in this paragraph are to issue s of Teachers' Aid.

[4] Teachers'Aid, 1900, 31, p. 112.

[5] Teachers'Aid, 1900, 31, pp. 516-517.

[6] Teachers'Aid, 1899, 29, p. 581.

[7] Teachers'Aid, 1899, 29, pp. 226-227.

[8] Birmingham School Board Minutes, vol. 6, 1888-90. 
Recebido em: 06/11/2012

Aprovado em: 22/08/2012

Universidade do Estado de Santa Catarina - UDESC

Programa de Pós-Graduação em Educação - PPGE

Revista Linhas

Volume 14 - Número 26 - Ano 2013

revistalinhas@gmail.com 